\title{
An Early Triassic gladius associated with soft tissue remains from Idaho, USA-a squid-like coleoid cephalopod at the onset of Mesozoic Era
}

Larisa A. Doguzhaeva, Arnaud Brayard, Nicolas Goudemand, Laurel J. Krumenacker, James F. Jenks, Kevin G. Bylund, Emmanuel Fara, Nicolas Olivier, Emmanuelle Vennin, and Gilles Escarguel Acta Palaeontologica Polonica 63 (2), 2018: 341-355 doi:https://doi.org/10.4202/app.00393.2017

We describe an Olenekian (Early Triassic) "fossil squid" belonging to the oldest complex Mesozoic marine biota collected in the Lower Shale unit of the Lower Triassic Thaynes Group in Idaho, USA. The studied specimen shows a tapered structure embedded in a cylindrical soft body. Morphological, ultrastructural and geochemical features of the specimen suggest that it corresponds to an internally-shelled cephalopod exhibiting a tapered micro-laminated gladius with rachis, narrow median and lateral fields and a large conus; a pair of posterior large fin-supported cartilages and fins; ventral and dorsal mantle band-shape structures, the dorsal one being cartilaginous; mantle patches; a stomach containing undigested arm-hooks and sheet-like pieces of potential flooded ink. Coupled SEM/EDS analyses show that (i) arm-hooks and ink were pseudomorphed by nanoparticles (less than $0.6 \mathrm{~mm}$ in diameter) of carbon, (ii) gladius and soft tissues were substituted by granules of calcium phosphate, (iii) cartilage canalicula's were partially filled with calcium phosphate grains and crystals of $\mathrm{Zn}$ - and S-containing minerals. The specimen was hence probably fossilized due to metabolism of $\mathrm{P}$ - and $\mathrm{C}$-accumulating bacteria. Based on this specimen, Idahoteuthis parisiana Doguzhaeva and Brayard gen. et sp. nov. and Idahoteuthidae Doguzhaeva and Brayard fam. nov. are erected. This family is characterized by an elongated, cylindrical, dorsally cartilaginous muscular mantle; well-developed, about 0.2 mantle length, rounded anteriorly and acute posteriorly, fin-supported cartilages and similarly shaped two fins at conical mantle termination, and thin slender gladius with narrow median and lateral fields, rachis and breviconic conus. This family assumedly falls in Myopsida (Decabrachia). A streamlined body, large fin-supported cartilages and eroded arm-hooks in the stomach of Idahoteuthis Doguzhaeva and Brayard gen. nov. suggest that this was a maneuverable cannibal predator that dwelled in the subequatorial shallow sea of the west coast of Pangaea.

Key words: Cephalopoda, Coleoidea, phylogeny, gladius, soft tissue preservation, Triassic, USA, Idaho.

Larisa A. Doguzhaeva [larisa.doguzhaeva@gmail.com; larisa.doguzhaeva@nrm.se 
], Department of Palaeobiology, Swedish Museum of Natural History, P.O. Box 50007, SE-10405 Stockholm, Sweden. Arnaud Brayard [arnaud.brayard@bourgogne.fr ], Emmanuel Fara [emmanuel.fara@u-bourgogne.fr], and Emmanuelle Vennin [Emmanuelle.vennin@u-bourgogne.fr], Biogéosciences UMR6282, CNRS, Univ. Bourgogne Franche-Comté, 6 Boulevard Gabriel, 21000 Dijon, France. Nicolas Goudemand [nicolas.goudemand@ens-lyon.fr ], Université de Lyon, ENS de Lyon, CNRS, Université Claude Bernard Lyon 1, Institut de Gé nomique Fonctionnelle de Lyon, UMR 5242, 46 Allé e d'Italie, F-69364 Lyon Cedex 07, France; Laurel J. Krumenacker [ljkrumenacker@ gmail.com ], Department of Earth Sciences, Montana State University, P.O. Box 173480, Bozeman, Montana 59717-3480, USA. James F. Jenks [jenksjimruby@ gmail.com ], 1134 Johnson Ridge Lane, West Jordan, Utah 84084, USA. Kevin G. Bylund [kevin@ammonoid.com ], 140 South 700 East, Spanish Fork, Utah 84660, USA. Nicolas Olivier [nicolas. olivier@ univ-lyon1.fr ], Institute of Functional Genomics of Lyon, ENS Lyon-CNRS 5242-INRA USC 1370, 46 allée d'Italie, 69364 Lyon Cedex 07, France.

Gilles Escarguel [Gilles.Escarguel@univ-lyon1.fr], Laboratoire d'Ecologie des Hydrosystèmes Naturels et Anthropisés, UMR CNRS 5023, Université Claude Bernard Lyon 1, $27-43$ Boulevard du 11 novembre 1918, 69622 Villeurbanne Cedex, France.

This is an open-access article distributed under the terms of the Creative Commons Attribution License (for details please see creativecommons.org), which permits unrestricted use, distribution, and reproduction in any medium, provided the original author and source are credited.

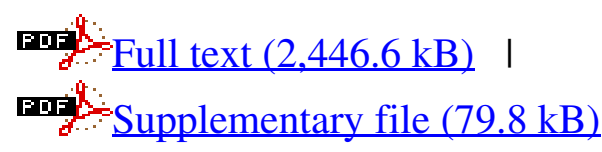

